\title{
Kromomikosis yang menyerupai karsinoma sel skuamosa: suatu kasus jarang
}

\author{
Shinta Ayu Intan, Salmiah Agus, Anandia Putriyuni \\ Bagian Patologi Anatomi, Fakultas Kedokteran, Universitas Andalas \\ Korespondensi: Shinta Ayu Intan, email: shintaayuintan md@yahoo.co.id
}

\begin{abstract}
Abstrak
Kromomikosis merupakan infeksi jamur kronik yang disebabkan oleh jamur berpigmen (dematiaceous) yang masuk ke dermis dari lingkungan sekitar. Kromomikosis mengenai laki-laki dewasa dengan rentang usia antara 40-50 tahun. Predileksi paling sering yaitu di ekstremitas bawah terutama kaki. Tanah, sayur-sayuran dan bahan organik lainnya merupakan habitat normal dari jamur ini. Tujuan: Melaporkan satu kasus kromomikosis jarang. Kasus: Dilaporkan kasus pada seorang laki-laki usia 53 tahun dengan bercak berwarna keabu-abuan tanpa rasa gatal dan nyeri yang semakin bertambah besar sejak \pm 1 tahun yang lalu pada pergelangan kaki kiri. Simpulan: Kromomikosis sering salah didiagnosis sebagai karsinoma sel skuamosa, konfirmasi histopatologi penting untuk menegakkan diagnosis karena pemeriksaan secara histopatologi menunjukkan gambaran khas yaitu adanya copper pennies sehingga dapat menyingkirkan diagnosis bandingnya.
\end{abstract}

Kata kunci: kromomikosis; karsinoma sel skuamosa; copper pennies

\section{Abstract}

Chromomycosis is a chronic fungal infection caused by pigmented (dematiaceous) fungi that are implanted into the dermis from the environment. Chromomycosis of adult males with age ranges between 40-50 years. Predilection is most common in the lower extremities, especially the legs. Soil, vegetables and other organic matter are the normal habitat of this fungus. Objectives: Reports a rare chromomycosis case. Case: We reported a case in a 53-year-old male with grayish plaque without itching and pain, it grew larger since \pm 1 year ago on the left ankle. Conclusions: Chromomycosis is often misdiagnosed as squamous cell carcinoma, histopathologic confirmation important for diagnosis because histopathologic examination shows a typical feature of copper pennies so as to exclude differential diagnoses.

Keywords: chromomycosis; squamous cell carcinoma; copper pennies 


\section{PENDAHULUAN}

Kromomikosis pertama kali dilaporkan oleh Alexandrio Pedroso pada tahun 1911 di Brazil. Penyakit ini merupakan infeksi jamur kronik kutan dan subkutan yang disebabkan oleh jamur berpigmen (dematiaceous) yang masuk ke dermis dari lingkungan sekitar. Sebagian besar infeksi ini disebabkan oleh Fonsecaea pedrosoi (73,01\%). Trauma kecil merupakan port $d^{\prime}$ entre dari infeksi ini. ${ }^{1,2}$

Penyakit ini terutama terdapat pada daerah tropis dan sub tropis. Kasus terbanyak yang dilaporkan terjadi di Amerika Latin, Asia, Afrika, Australia, dan Thailand. Di Indonesia belum ada data yang tercatat mengenai insiden kromomikosis ini. Kromomikosis terutama mengenai laki-laki dewasa dengan rentang usia antara 40-50 tahun. Riwayat pekerjaan sebagai petani, penebang pohon atau yang bekerja tidak menggunakan alat pelindung diri saat berkontak dengan tanah, sayur-sayuran yang membusuk, kayu-kayu lapuk dan bahan-bahan organik lainnya yang merupakan habitat normal dari jamur ini. ${ }^{3,4}$

Predileksi paling sering yaitu di ekstremitas bawah terutama kaki, berikutnya tangan, lengan dan bokong. Kasus sporadik yang pernah dilaporkan ditemukan di telinga, wajah, leher, payudara, dada, dan perut. $^{2}$

Gambaran klinis dari kromomikosis sering menyerupai penyakit lain seperti karsinoma sel skuamosa dan tuberkulosis kutis verukosa sehingga masih sering salah didiagnosis. Hal ini disebabkan karena perjalanan penyakit yang sangat singkat (1 tahun). ${ }^{1,5}$ Artikel ini bertujuan untuk melaporkan satu kasus kromomikosis pada tungkai bawah kiri pada laki-laki usia 53 tahun.

\section{LAPORAN KASUS}

Seorang laki-laki usia 53 tahun datang ke poliklinik Ilmu Kesehatan Kulit dan Kelamin RSUP dr. M. Djamil Padang pada tanggal 24 November 2015 dengan keluhan utama bercak berwarna keabu-abuan semakin bertambah besar sejak \pm 1 tahun yang lalu pada pergelangan kaki kiri. Bercak tersebut memiliki permukaan kasar dan tidak terasa gatal.

Riwayat penyakit sekarang diketahui bahwa awalnya berupa bintil kecil seperti kutil kemudian diobati dengan obat kutil berupa cairan yang di oleskan $2 x$ sehari. Setelah penggunaan obat selama 3 hari bintil sembuh dengan keropeng kehitaman pada permukaan lesi. Satu bulan kemudian timbul bintil baru sebesar jarum di lokasi yang sama. Bintil semakin lama semakin membesar kemudian membentuk bercak dengan permukaan kasar, tidak ada rasa gatal ataupun nyeri. Selama 2 tahun bercak keabu-abuan diobati dengan pengobatan tradisional dan obat kutil. Obat tersebut hampir setiap hari digunakan, namun bercak keabu-abuan tidak berkurang dan tidak pernah sembuh bahkan muncul bintil yang baru. Riwayat perdarahan spontan pada lesi ini tidak ada, riwayat trauma sebelumnya (kena tusukkan serpihan kayu) tidak ada, riwayat luka yang tidak pernah sembuh sebelumnya pada pergelangan 
kaki kiri tidak ada, riwayat batuk-batuk lama lebih dari 3 minggu tidak ada, riwayat konsumsi obat anti tuberkulosis (OAT) tidak ada, nafsu makan berkurang tidak ada dan penurunan berat badan drastis tidak ada. Pasien seorang petani kelapa sawit dan bekerja menggunakan sepatu dan kaos kaki setinggi pergelangan kaki.

Hasil pemeriksaan fisik diketahui bahwa keadaan umum sedang, kesadaran komposmentis, tekanan darah 110/70 $\mathrm{mmHg}$, frekuensi nadi $78 \mathrm{x} /$ menit, frekuensi napas 18x/menit. Berat badan 62 $\mathrm{kg}$, tinggi badan $165 \mathrm{~cm}, \mathrm{BMI}=22,3$ (normoweight). Pemeriksaan kulit, status dermatologikus: plak berwarna keabuabuan dengan permukaan verukosa, bintik-bintik coklat kehitaman di atasnya, krusta kekuningan, ekskoriasi ukuran $12 \times 7 \times 0,2 \mathrm{~cm}$ pada pergelangan kaki bagian anterior-lateral.

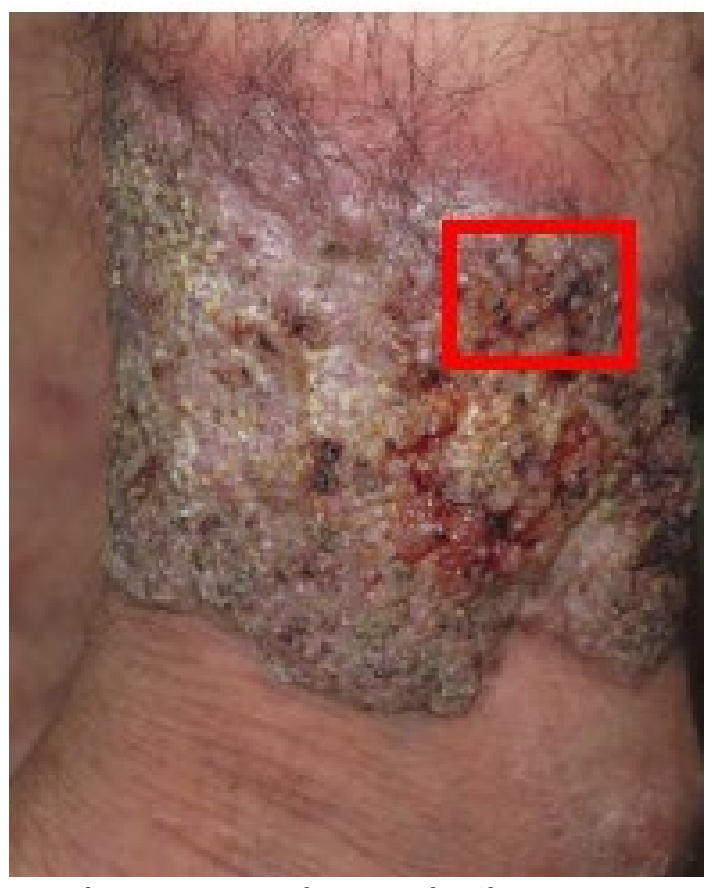

Gambar 1. Status dermatologikus
Pemeriksaan rutin dari kerokan kulit pergelangan kaki kiri dengan potasium hidroksida $20 \%$ (KOH 20\%) yang diteteskan di atas kaca slaid memberikan hasil (+) yaitu ditemukan adanya sclerotic bodies (dark-brown, thick walled, ovoid spore). Pasien didiagnosis klinis sebagai suspek karsinoma sel skuamosa pada pergelangan kaki kiri. Diagnosis banding dengan kromomikosis dan tuberkulosis kutis verukosa.

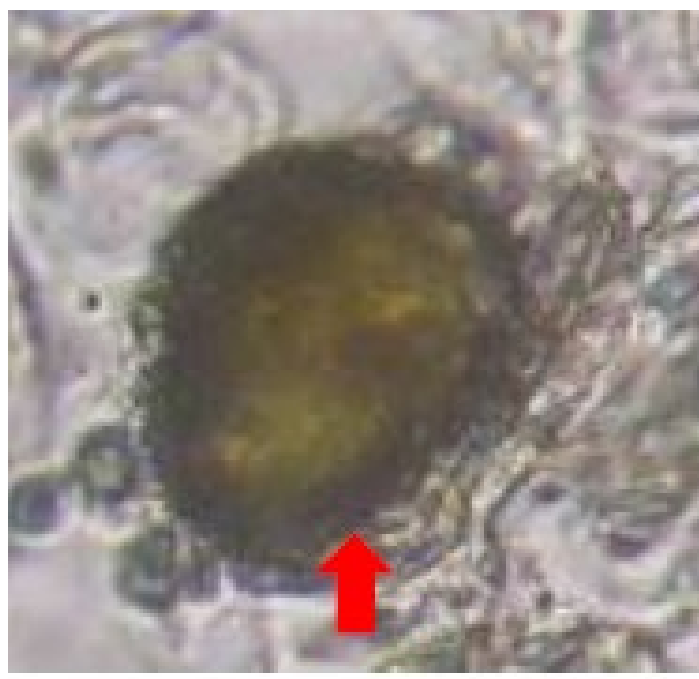

\section{Gambar 2. Pemeriksaan KOH 20\%, pembesaran $40 \times 10$}

Pada tanggal 24 November 2015 dilakukan biopsi eksisi pada jaringan kulit pergelangan kaki kiri dan jaringan biopsi eksisi dikirim ke Laboratorium Patologi Anatomi RSUP dr. M. Djamil Padang untuk pemeriksaan histopatologi. Makroskopik sepotong jaringan berkulit putih kecokelatan ukuran 1,5x0,5x0,3 cm. Mikroskopik dari sediaan yang dibuat tampak jaringan kulit dengan epidermis menunjukkan gambaran pseudoepitheliomatous hyperplasia (akantosis, hiperkeratosis dengan rete ridges memanjang seperti pita ke arah dermis) serta adanya 
kelompokkan neutrofil (mikroabses). Lapisan dermis terdiri atas stroma jaringan ikat yang mengandung sebukan dan kelompokan padat sel limfosit, histiosit, sel datia, sebaran sel neutrofil dan sel eosinofil. Pada beberapa tempat tampak adanya badan bentuk bulat oval dengan dinding tebal berwarna kecokelatan. Tampak juga adanya adneksa kulit serta jaringan lemak pada subkutan (Gambar 3). Diagnosis histopatologi kromomikosis.

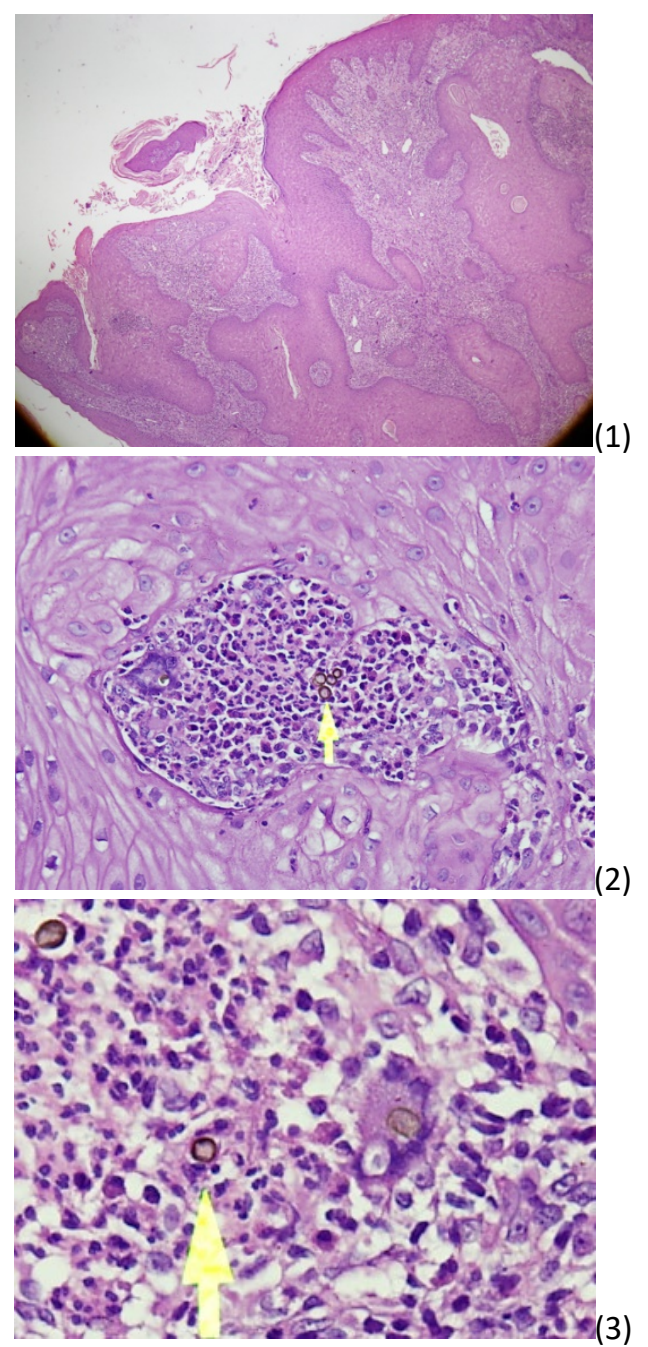

Gambar 3. Histopatologi kromomikosis. Berturut-turut (1) Pseudo-epitheliomatous hyperplasia (HE 4x10); (2) Kelompokan netrofil (mikroabses) (HE 20X10); (3) Sebukan, kelompokan padat sel limfosit, histiosit, sel datia, sebaran netrofil, eosinofil dan badan bentuk bulat oval dengan dinding tebal berwarna kecoklatan (HE 40X10).

Pasien diterapi dengan itrakonazol $2 \times 200 \mathrm{mg} /$ hari selama 1 minggu, pulse dose dan cetirizine $1 \times 10 \mathrm{mg}$. Pada tanggal 4 Desember 2015 pemeriksaan saat kontrol tampak bercak keabu-abuan di kaki mulai berkurang.

\section{PEMBAHASAN}

Kromomikosis adalah suatu penyakit infeksi jamur kronik di kulit dan subkutan yang sering ditemukan pada daerah tropis dan sub tropis.,7 Kromomikosis sering disebabkan oleh berbagai macam pigmented fungi (dematiaceous) seperti Fonsecaea pedrosoi, Phialophora verrucosa, Fonsecaea compactum, Wangiella dermatitidis, dan Cladophialophora carrionii. Mayoritas infeksi disebabkan oleh $F$. pedrosoi (terutama di Amerika Serikat) dan $C$. carrionii..$^{8-10}$

Kromomikosis biasanya terjadi laki-laki dewasa rentang usia 40-50 tahun. ${ }^{5,6,8,9}$ Penyakit ini paling sering ditemukan pada petani terutama laki-laki atau individu yang pekerjaannya berkontak dengan tanah ataupun sayuran. ${ }^{10}$ Jamur ini bersifat saprofit, bisa hidup di tanah, sayur-sayuran yang telah membusuk, dan serpihanserpihan kayu. ${ }^{11}$ Sebuah konsep yang menyatakan bahwa kromomikosis disebabkan oleh proses inokulasi didukung dari hasil observasi pada dua orang pasien yaitu penemuan elemen pigmentasi jamur pada serpihan kayu yang berkontak langsung dengan kulit pasien. Hal yang 
sama juga ditemukan pada petani yang bekerja tidak menggunakan alat pelindung diri saat berkontak dengan tanah, sayursayuran dan bahan-bahan organik lainnya yang merupakan habitat normal dari jamur ini. ${ }^{3,9}$ Pada kasus ini pasien adalah seorang laki-laki berusia 53 tahun dan bekerja sebagai petani kelapa sawit.

Gejala klinis yang ditemukan bervariasi, akan tetapi yang paling sering berupa bintil-bintil yang kemudian meluas perlahan-lahan menjadi bercak, benjolan yang verrucous yang dikelilingi area halo yang kemerahan serta adanya bintik hitam. ${ }^{5,10}$ Tanda ini sesuai dengan pasien yaitu berupa bercak berwarna keabuabuan dengan permukaan kasar dan semakin bertambah besar sejak \pm 1 tahun yang lalu pada pergelangan kaki kiri. Lokasi yang paling umum adalah kaki, tungkai, lengan dan batang tubuh bagian atas. ${ }^{5}$ Hubungan dengan trauma berkorelasi baik dengan keterlibatan ekstremitas yang dominan. ${ }^{11}$

Diagnosis klinis pasien ini yaitu suspek karsinoma sel skuamosa dan didiagnosis banding dengan kromomikosis, tuberkulosis kutis verukosa. Gambaran klinis dari kromomikosis sering menyerupai penyakit lain seperti karsinoma sel skuamosa dan tuberkulosis kutis verukosa. ${ }^{5}$ Karsinoma sel skuamosa memiliki karakteristik yaitu berupa tumor eksofitik dengan batas tidak jelas, tumbuh lambat dengan penampilan seperti kembang kol. Lesi tuberkulosis kutis verukosa diawali sebagai bintil kecil tanpa gejala dengan pertumbuhan lambat dan akan membentuk bercak verrucous yang tidak teratur. ${ }^{8,9}$

Diagnosis pasti dapat ditegakkan dengan pemeriksaan histopatologi. Gambaran histopatologi ditandai dengan adanya pseudoepithelimatous epidermal hyperplasia; sel epithelioid, histiosit yang ditemukan pada lapisan dermis. Infiltrat sel lainnya seperti sel besar berinti banyak; sejumlah sel limfosit, sel plasma, sel eosinofil dan kelompokan sel neutrofil. Struktur tuberkuloid dapat ditemukan, akan tetapi tidak ditemukan adanya nekrosis kaseosa. ${ }^{6}$

Secara histopatologi gambaran pseudoepithelimatous

epidermal hyperplasia dengan infiltrat sel radang kronik yang membentuk mikroabses juga dapat ditemukan pada infeksi kulit lainnya seperti sporotrikosis dan tuberkulosis kutis verukosa. Sporotrikosis dimana karakteristiknya inflamasi supuratif lebih nyata dan adanya gambaran sporothrix asteroid (the Splendore-Hoeppli phenomenon). ${ }^{12,13}$ Tuberkulosis kutis verukosa karakteristiknya berupa sel epiteloid, sel datia dan granuloma kaseosa. ${ }^{14}$ Sehingga untuk memastikan suatu kromomikosis secara histopatologi harus ditemukan adanya badan ovoidspheris. Jamur dapat ditemukan terutama pada area abses di lapisan dermis. Bentuknya oval, berdinding tebal, berwarna coklat kehitaman dengan ukuran 6-12 $\mu \mathrm{m}$, dikenal sebagai copper pennies, sclerotic bodies, muriform cells atau Medlar bodies yang bisa ditemukan tunggal ataupun berkelompok. ${ }^{15-18}$ Copper 
pennies pada lapisan dermis dapat terlihat tanpa pewarnaan khusus. ${ }^{19}$ Pemeriksaan histopatologi pada pasien ini setelah biopsi eksisi didapatkan gambaran suatu kromomikosis.

Pemeriksaan lain melalui kerokan kulit terutama area dengan bintik hitam pada permukaan lesi, dengan menggunakan $\mathrm{KOH}$ 20-40\% menunjukkan jamur yang berwarna kecokelatan, berdinding tebal, dengan diameter 4-10 $\mu \mathrm{m}$. Hal ini sesuai dengan yang ditemukan pada pasien. ${ }^{9}$ Kultur agar sabouraud yaitu pada media agar yang mengandung antibiotik kemudian di inkubasi pada suhu $25-28^{\circ} \mathrm{C}$ menghasilkan pertumbuhan koloni jamur coklat kehitaman dengan permukaan licin (25-30 hari). ${ }^{9}$

Kromomikosis berkaitan dengan angka penyembuhan yang rendah dan tingkat kekambuhan yang tinggi terutama pada infeksi yang kronik dan luas. Pilihan pengobatan dan keberhasilan terapi bergantung kepada agen penyebab, ukuran, luas dan lokasi dari lesi. Adanya komplikasi merupakan faktor penting yang nantinya akan mempengaruhi pengobatan. Pada pasien yang datang dengan lesi awal dan berukuran kecil, tujuan pengobatan adalah penyembuhan sempurna. Walaupun pada beberapa kasus dengan lesi yang luas dengan pengobatan jangka panjang mungkin tingkat keberhasilan pengobatan sedikit atau hanya pengurangan dari luas lesi sehingga kontrol penyakit ini dibutuhkan untuk mencegah terjadinya komplikasi seperti lokal limfadema, yang mengarah pada elefantiasis dan squamous carcinoma pada beberapa lesi yang kronik. ${ }^{9,20,21}$

Terapi utama untuk kromomikosis adalah itrakonazol 2×200 mg/hari; terbinafin 250 $\mathrm{mg} /$ hari; dan dalam kasus yang terjadi secara luas diberikan amfoterisin B intravena (sampai $1 \mathrm{mg} / \mathrm{kg}$ sehari). ${ }^{9}$ Pada pasien ini terapi yang diberikan adalah itrakonazol $2 \times 200 \mathrm{mg} /$ hari selama 1 minggu, pulse dose dan cetirizine $1 \times 10 \mathrm{mg}$.

Prognosis kromomikosis secara keseluruhan baik. Pada pasien ini prognosis kromomikosis ragu ke arah baik, mengingat pasien bekerja sebagai petani dan infeksi ini bersifat kronik residif sehingga dibutuhkan proteksi yang memadai dalam bekerja.

\section{SIMPULAN}

Kromomikosis merupakan suatu kasus yang jarang ditemukan, dimana kelainan ini sering salah didiagnosis sebagai karsinoma sel skuamosa. Pemeriksaan histopatologi penting untuk mendiagnosis kromomikosis, karena pemeriksaan secara histopatologi menunjukkan gambaran yang khas yaitu adanya gambaran copper pennies sehingga dapat menyingkirkan diagnosis bandingnya. 


\section{DAFTAR PUSTAKA}

1. Roy AD, Dipmala D, Deka M. Chromoblastomycosis - A clinical mimic of squamous carcinoma. Australas Med J. 2013; 6(9):458-460. doi: 10.4066/AMJ.2013.1806.

2. Santos AL, Palmeira VF, Rozenthal S, Kneipp LF, Nimrichter L, Alviano DS, et al. Biology and pathogenesis of Fonsecaea pedrosoi, the major etiologic agent of chromoblastomycosis. FEMS Microbiol Rev. 2007; 31(5):570-91. doi: 10.1111/i.1574-6976.2007.00077.x.

3. Quieroz-Telles F. Chromoblastomycosis: A Neglected Tropical Disease. Rev Inst Med Trop Sao Paulo. 2015; 57(Suppl. 19):46-50. doi: 10.1590/S0036-46652015000700009.

4. da Silva JP, Alviano DS, Alviano CS, de Souza W, Travassos LR, Diniz JA, et al. Comparison of Fonsecaea pedrosoi sclerotic cells obtained in vivo and in vitro: ultrasructure and antigenicity. FEMS Immunol Med Microbiol. 2002; 33(1):63-69. doi: 10.1111/i.1574-695X.2002.tb00574.x.

5. Patterson JW. Mycoses and Algae Infections. In: Patterson JW. Weedon's Skin Pathology. Philadelphia: Elsevier; 2015. P.703-4.

6. Elder DE. Fungal Disease. In: Elder DE, Elenitsas R, Rosenbach M, Murphy GF, Rubin Al, Xu X, editors. Lever's Histopathology of the Skin. $11^{\text {th }}$ Edition. Philaderpia: Lippincott Williams \& Wilkins; 2011. P.744-746.

7. Patterson JW. Chromomycosis. In: Patterson JW. Practical Skin Pathology A Diagnosis Approach. Philadelphia: Saunders; 2013. P.281-282.

8. Hay RJ, Ashbee HR. Mycology. In: Burns T, Breathnach S, Cox N, Griffiths C, editors. Rook's Textbook of Dermatology. $8^{\text {th }}$ Edition. New Jersey: Willey-Blackwell Ltd; 2010: 36.1-36.93.

9. Hay RJ. Deep Fungal Infections. In: Goldsmith LA, Katz SI, Gilchrest BA, Paller AS, Leffell DJ, Wolff $K$, editors. Fitzpatrick Dermatology in General Medicine. $8^{\text {th }}$ Edition. New York: McGraw Hill; 2012: P.1286-1294.

10. Lucas S. Bacterial Disease. In: Elder DE, Elenitsas R, Rosenbach M, Murphy GF, Rubin Al, Xu X, editors. Lever's Histopathology of the Skin. $11^{\text {th }}$ Edition. Philadelphia: Lippincott Williams \& Wilkins; 2011. P.562-566.

11. Brinster N, Liu V, Diwan D, McKee P. Infectious Dermatitis, Fungal Infection. In: High-Yield Pathology Dermatopathology. Philadelphia: Elsevier; 2011. P.256.

12. Chandran V, Sadanandan S, Sobhanakumari K. Chromoblastomycosis in Kerala, India. Indian J Dermatol Venereol Leprol. 2012; 78(6):728-733. doi: 10.4103/0378-6323.102366.

13. McKee PH, Calonje E, Granter SR. Pathology of the Skin with Clinical Correlation. $3^{\text {rd }}$ Edition. Maryland Heights: Mosby; 2005.

14. Sethi A. Tuberkulosis and Infections with Atypical Mycobacterium. In: Wolff K, Goldsmith LA, Katz SI, Gilchrest BA, Paller AS, Leffel DJ, editors. Fitzpatrick dermatology in general medicine. $8^{\text {th }}$ edition. New York: McGraw Hill; 2012. P.2261-2269.

15. Aliağaoğlu C, Atasoy M, Güleç Al, Özdemir Ş, Erdem T, Engin RI. Tuberculosis Cutis Verrucous. J European of General Medicine. 2009; 6(4):268-273.

16. Busam K. Infectious Diseases of the Skin. In: Dermatopathology. Philadelphia: Elsevier; 2010. 
17. Ko CJ, Barr RJ. Shape on Low Power, "Pseudoepithelimatous Hyperplasia Above Abcesses". In: Ko CJ, Barr RJ, editors. Dermatopathology: Diagnosis by First Impression. $2^{\text {nd }}$ Edition. New Jersey: Wiley-Blackwell; 2011. P.1-20.

18. Rapini RP. Fungal Diseases. In: Rapini RP. Practical Dermatopthology. Philadelphia: Elsevier; 2005.

19. Procop G, Pritt B. Dematiaceous Fungal Infection. In: Procop G, Pritt B. Pathology of Infectious Diseases. Philadelphia: Elsevier; 2015.

20. Sterry W, Paus R, Burgdorf W. Thieme Clinical Companions Dermatopathology. Stuttgart: Thieme; 2007. P.118.

21. Krzyściak PM, Pindycka-Piaszczyńska M, Piaszczyński M. Chromoblastomycosis. Postepy Dermatol Alergol. 2014; 31(5):310-21. doi: 10.5114/pdia.2014.40949. 